\title{
Legacy Effects of Explosive Contamination on Vegetative Communities
}

\author{
Stephen M. Via, Julie C. Zinnert, Donald R. Young \\ Department of Biology, Virginia Commonwealth University, Richmond, VA, USA \\ Email: jczinnert@vcu.edu
}

Received 21 June 2016; accepted 18 July 2016; published 21 July 2016

Copyright (C) 2016 by authors and Scientific Research Publishing Inc.

This work is licensed under the Creative Commons Attribution International License (CC BY). http://creativecommons.org/licenses/by/4.0/

(c) (i) Open Access

\begin{abstract}
Natural selection processes are constantly influencing vegetation community composition. In the presence of anthropogenic contaminants additional forces act as filters controlling persistence of naturally occurring species. Classical species diversity and richness metrics can miss subtle changes under disturbance regimes while species composition and functional characteristics may be able to detect them. Our study was designed to investigate legacy impacts of explosives contaminated soils in an experimental minefield on vegetative communities using ecological metrics. As hypothesized, species diversity and richness showed no change in the presence of explosive compounds while species composition provided clear separation of groups and functional trait dominance was also observed to change. Overall, presence of anthropogenic contaminates have led to community composition and functional shifts for vegetation after initial contamination. The responses in species composition and functional diversity/richness were a result of new tolerant species filling open niches in contaminated plots. More work is needed to confirm this in varied systems and in the presence of diverse contaminants.
\end{abstract}

\section{Keywords}

RDX, TNT, Composition B, Functional Traits, Community

\section{Introduction}

Natural selection pressures act as filters for establishment and succession of vegetative species. Via dispersal, environmental, and physiological filters, community composition develops to best befit the condition of any given area [1] [2]. Presence of anthropogenic contaminants adds an additional filter to the system, reducing fecundity of sensitive species, and increasing that of tolerant ones [3]. Loss or suppression of dominant/key species can have significant effects on ecosystem function [4], but even changes in non-dominant species density 
may have significant community level impacts [5]. Community shifts have been previously investigated and documented for a range of anthropogenic contaminants [6] [7] from mining operations [8]-[10] to radiation exposure [11]. Richness and diversity of plant species and functional diversity may be vital to ecosystem stability and function [12]-[15].

Long term impacts of contaminants on vegetation are studied less than shorter exposures [3]. This poses a problem as many anthropogenic contaminants are recalcitrant (i.e. heavy metals, explosives, agrochemicals, etc.) [16]-[18] when released into the environment and elicit chronic stress for many years in surrounding flora and fauna [19]. Even short term exposure to anthropogenic contaminants may have long-lasting implications [20]. The persistent nature of these compounds adds to this complexity of community level responses. Chronic exposure over extended periods of time has significant impacts on established communities [4] [21] [22] and the seedbank of contaminated areas [23] [24].

Once released into the environment anthropogenic contaminants exhibit a range of behaviors [19] [25]. Some rapidly bind to soil particles, while others are not constrained to a static location [26]. Compound mobility and structure play large roles in contaminant behavior in the environment [27]. For example, heavy metals behave differently from pharmaceuticals, agrochemicals, and explosives [28] [29]. Nanoparticles of a particular element behave very differently than larger particles of the same element [30]. Just as there are numerous behaviors of contaminants, responses of vegetation to these compounds are greatly varied.

Impacts on vegetation can range from morphological damage to physiological interruptions and exact response depends on the contaminant and plant species in the target area. Plant functional traits (e.g. life history, leaf morphology, root structure, photosynthetic pathway, etc...) can also influence response to stress [31]-[33] and ability to persist in contaminated conditions. As plants age, biochemical processes change [34]-[36], which may cause variations in response at different life stages. Mature plants have more biomass relative to earlier life stage which may allow the plant to withstand stress associated with the explosive compounds and then recover [37]. There are dualities present with tolerance to contaminants; plants capable of surviving may be harmed more as exposure time increases or may pass the contaminant through the system [38]. High variability in impacts on vegetation based on species, functional group, and even life stage adds a selection pressure to con- taminated areas.

Our study objective was to investigate long term impacts of explosives presence on the current vegetative community of a minefield contaminated 17 years prior with three different explosive compounds/mixtures. We hypothesized that 1) community richness and diversity in contaminated areas would not exhibit change from reference plots as species fill in vacant niches, 2) species composition would differ from reference plots as presence of contaminants filter out intolerant species, and 3) changes in species functional traits would differ in contaminated treatment plots from reference.

\section{Materials and Methods}

\subsection{Contaminants}

The two most commonly used explosive compounds are hexahydro-1,3,5-trinitro-1,3,5-triazine (RDX) and 2-methyl-1,3,5-trinitrobenzene (TNT). These compounds are the most widely distributed organic explosive contaminates found in the environment [17] [39] [40] and both can have significant impacts on vegetation health. Munitions contain either a single compound (TNT most commonly) or more commonly, a mixture of compounds (TNT and RDX). Composition B (Comp B) a mixture of RDX (60\%) and TNT (40\%) is a historically common munitions mixture. It was used extensively throughout World War II up through the 1950s, and is still used today [41].

\subsection{Study Site}

Data were collected from a privately owned experimental minefield in South Carolina, USA (33 54 '5.39"N, $82^{\circ} 2^{\prime} 1.79 " W$ ) [42] [43] (Figure 1). Geologically the site is located on the Carolina terrane (ct) composed of clastic rocks in the upper region and intermediate to felsic pyroclastic rocks $(>3 \mathrm{~km})$ in the lower. The soil at the plots was Herndon very fine sandy loam and Kirksey silt loam, both with 2\% - 6\% slopes [44].

The property was owned and managed by Force Protection Inc. at the time of data acquisition. Initially used for a microbial study in 1999 this site was razed to the ground and sectioned off into $5 \times 5$ m plots. Within a 


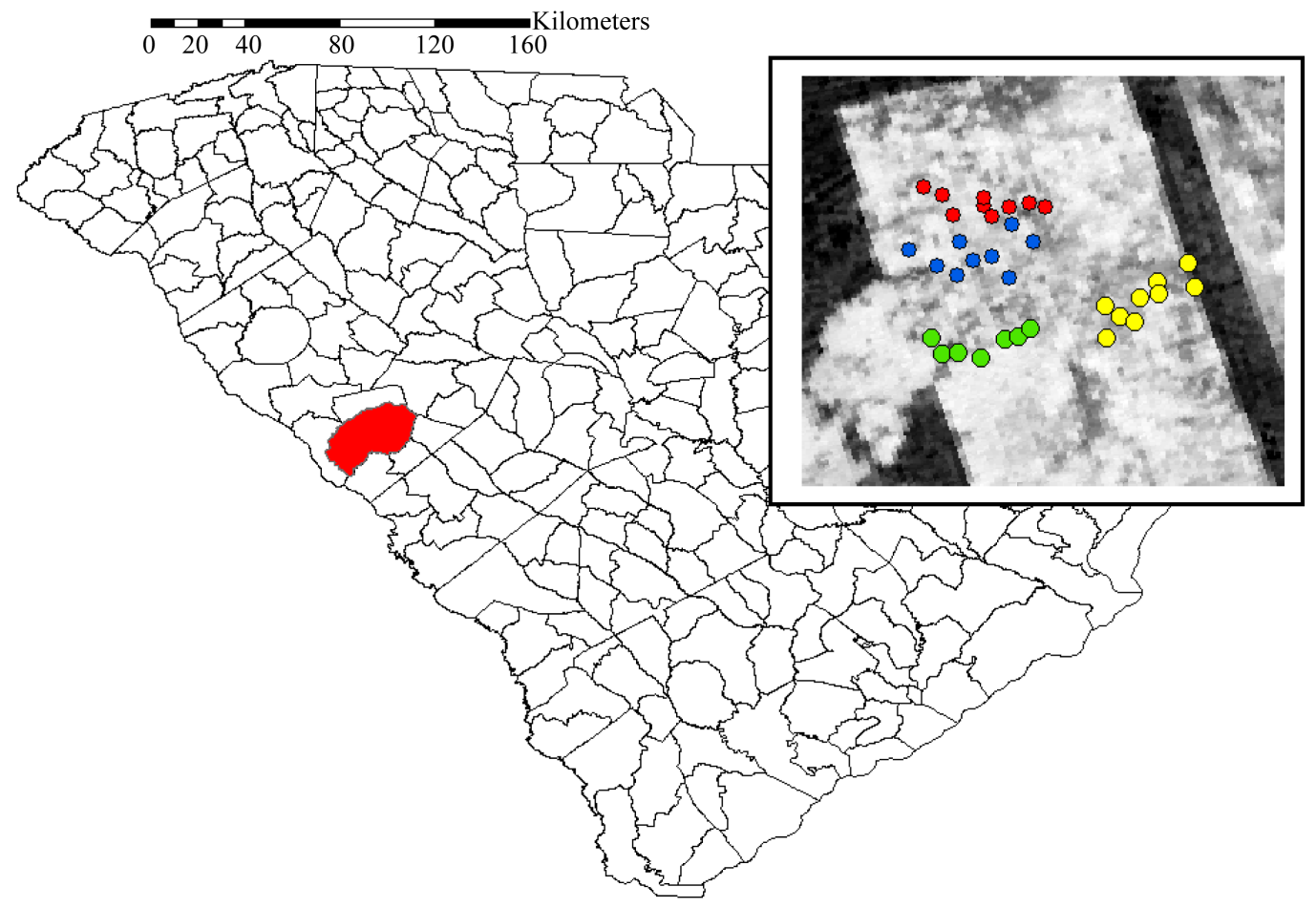

Figure 1. Location of field sites in Edgefield County, South Carolina. Colored circles show field plots where data was collected. Red marks reference plots, yellow marks RDX plots, blue TNT, and green Composition B.

number of those plots explosive compounds were buried in "dummy landmines" to mimic leaching of explosives from unexploded ordnance (UXOs). These dummy mines were boxes filled with TNT (2-methyl-1,3,5trinitrobenzene) and RDX (hexahydro-1,3,5-trinitro-1,3,5-triazine), or a mixture of the two compounds, Composition B (Comp B). Comp B is comprised of 60\% RDX, 39\% TNT, and 1\% wax binder. Dummy mines were designed to be similar to antipersonnel landmines and contained between 75 - $125 \mathrm{~g}$ of the designated explosive compound [45] [46]. Reference areas were established upslope of the contaminated plots in the razed area. Once the dummy mines had been planted the area was left to naturally revegetate.

In each of the treatment and reference areas $1 \times 1 \mathrm{~m}$ plots were delineated (Figure 1) and contaminated plots were checked using site maps from the property owner prior to data collection to ensure presence of a dummy mine. Herbaceous species were identified and percent cover established in each plot. Woody species abundance was also collected after the species had been identified. Minimally destructive metrics were used due to site protocol.

\subsection{Species Diversity}

Density and frequency were calculated for all species. Species richness (S; Equation (1)), Shannon-Weiner (H'; Equation (2)), and Simpson ( $D_{1}$; Equation (3)) metric values were calculated for total species as well as herbaceous and woody species separately. Both $\mathrm{H}^{\prime}$ and $\mathrm{D}_{1}$ were used to take into consideration both rare, and common species respectively [47] [48]. Plants not readily identifiable in the field were transported to the lab and identified using Radford et al. (2010) [49]. All species metrics were compared across treatment groups via analysis of variance (ANOVA) using a Tukey's post hoc test.

Equation (1). Equation for calculating species richness $(S)$ where " $s$ " is the number of species present and " $N$ " represents the number of individuals present.

$$
S=\frac{S}{\sqrt{N}}
$$

Equation (2). Equation for calculating Shannon-Weiner $\left(H^{\prime}\right)$ values where " $p_{i}$ ” is the proportional abundance 
of species "i” in the plots.

$$
H^{\prime}=-\sum_{i=1}^{R} p_{i}\left|\ln \left(p_{i}\right)\right|
$$

Equation (3). Equation for calculating Simpson $\left(D_{1}\right)$ values where " $p_{i}$ " is the proportional abundance of species " $i$ " in the plots.

$$
D_{1}=\sum_{i=1}^{R} p_{i}^{2}
$$

\subsection{Species Composition}

Jaccard's index of similarity was calculated for total, herbaceous, and woody species composition to investigate whether similarities in species composition were present across groups. Cluster analysis (with Sorenson distance) was used to determine how the plots relate to one another based on species composition. A dendrogram was constructed using PC-Ord (MjM Software Design) to visually represent the cluster analysis results. To determine if the resulting groups were significantly different, a multi-response permutation procedure (MRPP) was used (with Sorenson distance). MRPP was followed by pairwise comparison to compare species composition among groups.

\subsection{Functional Trait Composition}

Due to constraints on site access, functional trait data for all species recorded in the field were aggregated from literature sources [49]-[53]. Functional traits included: life history, native status, growth form, habit, maximum height, root structure, leaf morphology, seed size, dispersal mechanism, and photosynthetic pathway. To standardize trait values, community weighted mean (CWM) for each plot were calculated using the FD package in R [54] [55]. CWM allows categorical and continuous functional traits to be weighted by abundance of representative species, limiting any bias which may come from rare species or traits. This allows for the identification of dominant traits and provides insight into ecosystem processes [56]. CWM values for each functional trait were compared across treatment groups via ANOVA and Tukey's post-hoc test. Values were also used in a cluster analysis and MRPP (both with Sorenson distance) to investigate plot grouping. MRPP was followed by a pairwise comparison to compare species composition among groups.

\section{Results}

\subsection{Species Diversity}

Woody species density was variable across treatment groups for most species with Composition B plots distinguishing themselves from both reference and other treatment plots (Figure 2). RDX and TNT showed no significant change in woody species density compared to reference plots. Comp B plots exhibited significantly higher density for Ulmus alata Michx. ( $\mathrm{F}=6.40, \mathrm{p}<0.01)$ and Quercus virginiana Mill. $(\mathrm{F}=3.92, \mathrm{p}=0.02)$ relative to reference values ( $\mathrm{p}<0.01$ and $\mathrm{p}<0.01$, respectively). Ligustrum sinensce Lour, an invasive species, was common across all sites $(\mathrm{F}=2.15, \mathrm{p}=0.11$ ) but was significantly more dense in Comp $\mathrm{B}$ treated areas when compared to densities in TNT plots $(\mathrm{p}=0.02)$. Diospyros virginiana $\mathrm{L}$. was the only woody species which exhibited a significantly reduced presence in all three contaminated areas relative to reference (Figure 1; $F=6.11, p$ $<0.01$ ). Density of the other three woody species was similar across treatments; however, only one of those, Rhus copallina L., was present in abundance (Figure 2).

No differences were observed in richness, diversity, or Simpson index for herbaceous and woody species combined ( $\mathrm{p}<0.05$; Table 1). Separating out herbaceous and woody species did provide some differentiation of treatment groups. Species richness remained unchanged for herbaceous species yet woody species showed significant variation $(\mathrm{F}=3.37, \mathrm{p}=0.03)$, between Composition $\mathrm{B}$ and both RDX and TNT. Shannon-Weiner diversity, which is sensitive to rare species, was significantly different for herbaceous $(F=4.41, p=0.01)$ and woody $(\mathrm{F}=3.79, \mathrm{p}=0.02)$ plant communities (Table 1$)$. Only woody species showed a significant difference between the reference and treatment groups. Simpson's index, which is sensitive to abundant species, also showed significant differences between treatment groups in herbaceous and woody species (Table 1). This metric was the 


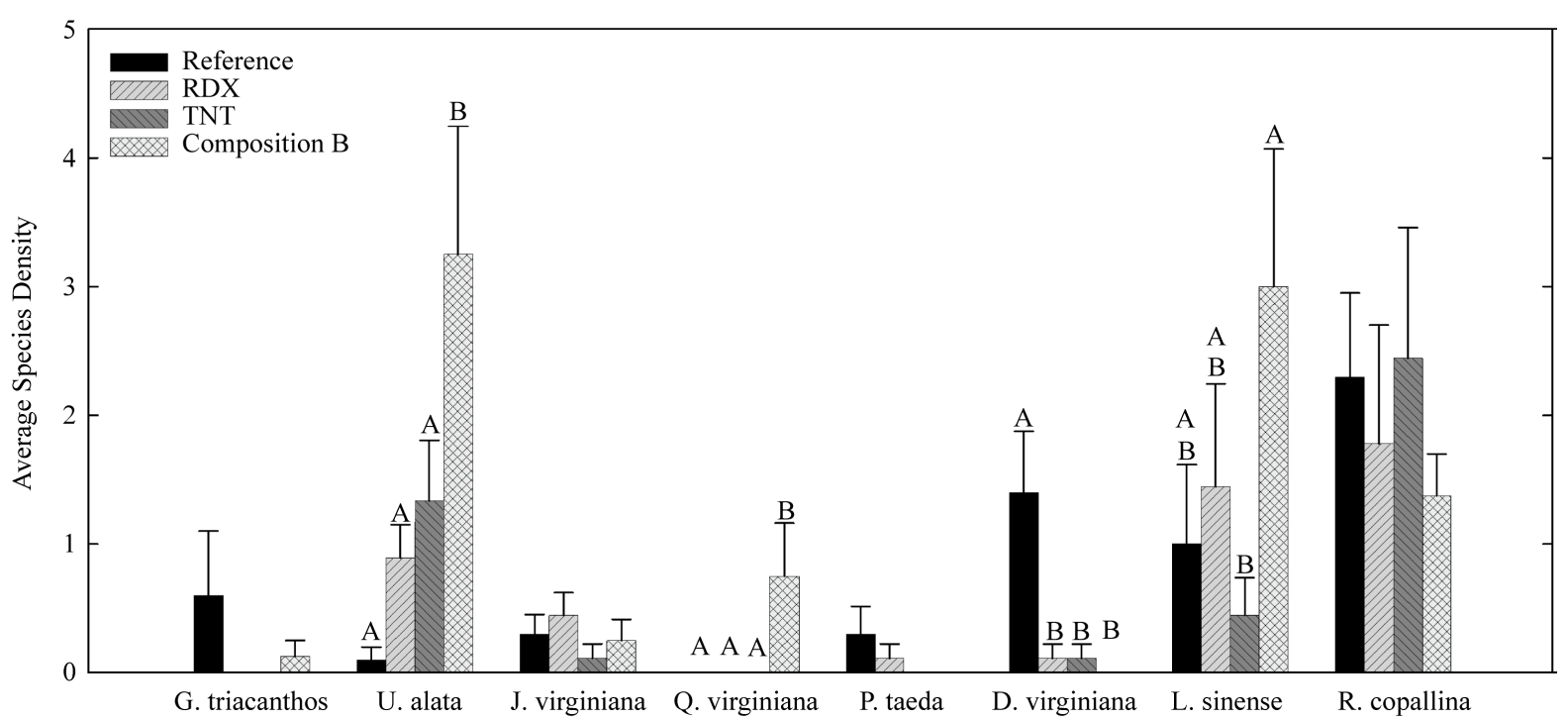

Figure 2. Woody species density across treatment types for reference and explosives contaminated plots. Letters denote statistical grouping. The lack of letter codes signifies that no difference was present between treatments.

Table 1. Mean and standard error of diversity metrics (richness $[S]$, Shannon-Weiner $\left[H^{\prime}\right]$, and Simpson index $\left[D_{1}\right]$ values) for reference and explosives contaminated plots.

\begin{tabular}{lcccccccc}
\hline \multicolumn{1}{c}{ Diversity Indices } & & Reference & RDX & TNT & Composition B & F & p \\
\hline \multirow{2}{*}{ All Species } & $\boldsymbol{S}$ & $9.90 \pm 0.75$ & $8.78 \pm 0.55$ & $8.22 \pm 0.66$ & $8.63 \pm 0.73$ & 1.18 & 0.33 \\
& $\boldsymbol{H}^{\prime}$ & $2.27 \pm 0.07$ & $2.16 \pm 0.06$ & $2.08 \pm 0.08$ & $2.13 \pm 0.09$ & 1.12 & 0.36 \\
& $\boldsymbol{D}_{\mathbf{1}}$ & $0.89 \pm 0.01$ & $0.88 \pm 0.01$ & $0.87 \pm 0.01$ & $0.88 \pm 0.01$ & 1.08 & 0.37 \\
& $\boldsymbol{S}$ & $7.30 \pm 0.62$ & $7.00 \pm 0.37$ & $6.33 \pm 0.53$ & $5.75 \pm 0.67$ & 1.51 & 0.23 \\
Herbaceous Species & $\boldsymbol{H}^{\prime}$ & $1.01 \pm 0.10$ & $1.25 \pm 0.07$ & $0.78 \pm 0.07$ & $0.92 \pm 0.13$ & 4.41 & 0.01 \\
& $\boldsymbol{D}_{\mathbf{1}}$ & $0.47 \pm 0.05$ & $0.61 \pm 0.03$ & $0.35 \pm 0.03$ & $0.45 \pm 0.07$ & 5.32 & $<0.01$ \\
& $\boldsymbol{S}$ & $2.78 \pm 0.32$ & $2.11 \pm 0.26$ & $2.00 \pm 0.19$ & $3.13 \pm 0.35$ & 3.37 & 0.03 \\
& $\boldsymbol{H}^{\prime}$ & $0.88 \pm 0.12$ & $0.52 \pm 0.13$ & $0.55 \pm 0.10$ & $0.98 \pm 0.12$ & 3.79 & 0.02 \\
& $\boldsymbol{D}_{\mathbf{1}}$ & $0.53 \pm 0.05$ & $0.32 \pm 0.08$ & $0.36 \pm 0.07$ & $0.57 \pm 0.06$ & 3.54 & 0.03 \\
\hline
\end{tabular}

only one to show a significant difference between the reference and a treatment group for both vegetation types. Overall it appeared that abundant species, rather than rare ones, were better able to differentiate reference and treatment communities suggesting shifts in species dominants with presence of explosives contamination.

\subsection{Species Composition}

Jaccard's index of similarity revealed that community composition across treatments was between $40 \%$ and $60 \%$ similar to one another (Table 2). Herbaceous community had similar values. The woody assemblage exhibited the least amount of similarity among treatments groups ranging from $14 \%$ to $43 \%$. The reference in particular saw a large reduction for woody species exhibiting only $14 \%-28 \%$ similarity.

Cluster analysis of species composition across treatments delineated three very distinct groups: 1 ) reference plots, 2) single contaminant plots (RDX and TNT), and 3) mixed contaminant plots (Composition B; Figure 3). Dendrogram grouping was supported by multi-response permutation procedure (MRPP) of species composition. MRPP showed that communities present in the plots were able to define the preexisting grouping scheme $(\mathrm{A}=$ $0.11, \mathrm{p}<0.01)$. Pairwise comparisons showed that reference communities were significantly different from those in contaminated areas as well as separate single compound contaminant plots (RDX and TNT) from mixed 
Table 2. Jaccard's index of similarity values for reference (Ref) and explosives contaminated plots.

\begin{tabular}{ccccccccccccc}
\hline Treatment & \multicolumn{3}{c}{ All Species } & \multicolumn{3}{c}{ Herbaceous Species } & \multicolumn{3}{c}{ Woody Species } \\
\hline & Ref & RDX & TNT & Comp B & Ref & RDX & TNT & Comp B & Ref & RDX & TNT & Comp B \\
\hline Reference & -- & & & & -- & & & & -- & & \\
RDX & 51.00 & -- & & & 61.00 & -- & & & 14.00 & -- & \\
TNT & 50.00 & 50.00 & -- & & 59.00 & 62.00 & -- & & 29.00 & 17.00 & -- & \\
Comp B & 44.00 & 46.00 & 60.00 & -- & 48.00 & 48.00 & 59.00 & -- & 29.00 & 43.00 & 33.00 & -- \\
\hline
\end{tabular}

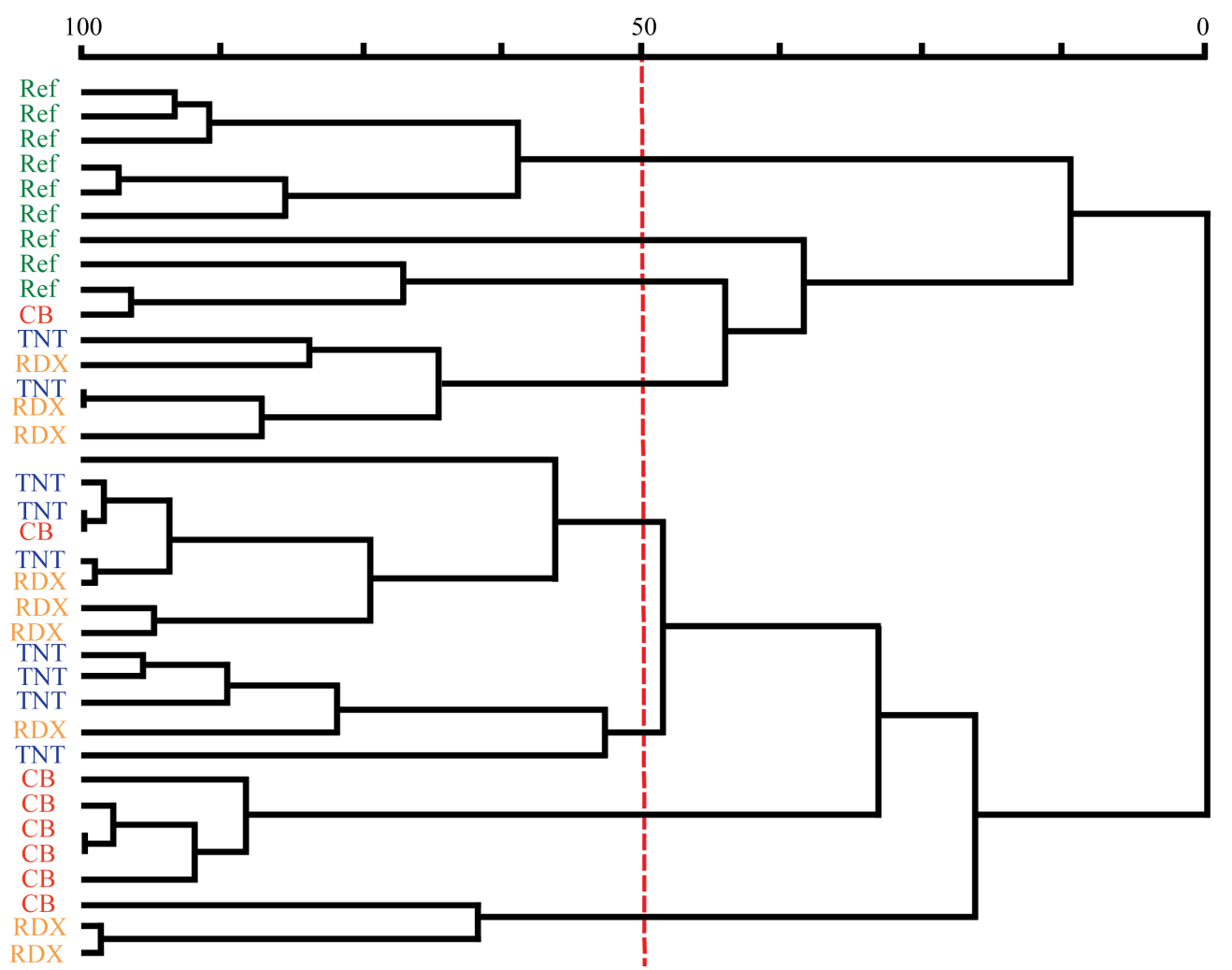

Figure 3. Dendrogram of plots based on species composition for reference and explosives contaminated plots. Axis along the top represent information remaining and the red dashed line represents the cutoff point used here.

compound treatment plots (Comp B). RDX and TNT were not different from one another based on species composition (Table 3).

\subsection{Functional Composition}

The number of species representing animal dispersed $(F=3.15, p=0.04)$, annual $(F=7.91, p<0.01)$, graminoid $(\mathrm{F}=6.19, \mathrm{p}<0.01)$, invasive $(\mathrm{F}=3.14, \mathrm{p}=0.03)$, monocot $(\mathrm{F}=5.45, \mathrm{p}<0.01)$, perennial $(\mathrm{F}=3.41, \mathrm{p}=0.03)$, trailing $(\mathrm{F}=3.88, \mathrm{p}=0.02)$, tree $(\mathrm{F}=4.730, \mathrm{p}<0.01)$, and vine $(\mathrm{F}=5.26, \mathrm{p}<0.01)$ functional groups were significantly different between groups (Table 4). RDX plots were most often responsible for the detected differences, exhibiting far more annual $(p<0.01)$, monocot $(p=0.02)$, graminoid $(p<0.01)$, trailing $(p=0.02)$, and vine $(\mathrm{p}<0.01)$ species, as well as fewer animal dispersed species $(\mathrm{p}=0.04)$ relative to reference. RDX also distinguished itself from TNT and Comp B plots with significantly higher counts of vine (Comp B p = 0.03), grass (TNT p $<0.01$, Comp B p = 0.01), annual (Comp B p =0.02), and monocot (TNT p < 0.01, Comp B p = 0.02) species. Additionally Comp B plots exhibited elevated numbers of tree and invasive species but was only significantly different from TNT plots ( $\mathrm{p}<0.01$ and $\mathrm{p}=0.02$ respectively). 
Table 3. P-values from pairwise comparisons of species and functional composition of treatment groups according to multi response permutation procedure (MRPP) analysis for reference and explosives contaminated plots.

\begin{tabular}{cccccccccc}
\hline Treatment & \multicolumn{3}{c}{ Species } & & & \multicolumn{2}{c}{ Functional Type } \\
\hline & Reference & RDX & TNT & Comp B & Reference & RDX & TNT & Comp B \\
\hline Reference & -- & & & -- & & \\
RDX & 0.0013 & -- & & 0.5425 & -- & \\
TNT & 0.0003 & 0.0822 & -- & & 0.3363 & 0.2741 & -- & -- \\
Composition B & 0.0014 & 0.0011 & 0.0074 & -- & 0.6403 & 0.2840 & 0.6207 & - \\
\hline
\end{tabular}

Bold text indicates the presence of a significant difference $(\mathrm{p}<0.05)$.

Table 4. Mean and standard error of species count in each treatment for various functional types for reference and explosives contaminated plots.

\begin{tabular}{|c|c|c|c|c|c|}
\hline \multicolumn{2}{|c|}{ Functional Trait } & \multirow{2}{*}{$\begin{array}{c}\text { Reference } \\
0.90 \pm 0.23^{\mathrm{a}}\end{array}$} & \multirow{2}{*}{$\begin{array}{c}\text { RDX } \\
2.56 \pm 0.30^{\mathrm{b}}\end{array}$} & \multirow{2}{*}{$\begin{array}{c}\text { TNT } \\
1.78 \pm 0.22^{\mathrm{a}}\end{array}$} & \multirow{2}{*}{$\begin{array}{c}\text { Comp B } \\
1.38 \pm 0.26^{\mathrm{a}, \mathrm{b}}\end{array}$} \\
\hline Life History & Annual & & & & \\
\hline & Biennial & $1.80 \pm 0.33$ & $1.33 \pm 0.24$ & $1.33 \pm 0.17$ & $1.00 \pm 0.27$ \\
\hline & Multiannual & $8.90 \pm 0.67$ & $6.56 \pm 0.58$ & $6.44 \pm 0.67$ & $7.75 \pm 0.82$ \\
\hline & Perennial & $7.10 \pm 0.57$ & $5.20 \pm 0.55$ & $5.11 \pm 0.56$ & $6.75 \pm 0.56$ \\
\hline \multirow[t]{5}{*}{ Dispersal Mechanism } & Zoochory & $5.70 \pm 0.73^{\mathrm{a}}$ & $3.56 \pm 0.15^{\mathrm{b}}$ & $3.78 \pm 0.57^{\mathrm{a}, \mathrm{b}}$ & $4.75 \pm 0.45^{\mathrm{a}, \mathrm{b}}$ \\
\hline & Ballochory & $0.20 \pm 0.13$ & $0.22 \pm 0.15$ & - & $0.13 \pm 0.13$ \\
\hline & Hydrochery & - & $0.11 \pm 0.11$ & - & - \\
\hline & Anemochory & $3.90 \pm 0.43$ & $5.22 \pm 0.32$ & $4.44 \pm 0.41$ & $4.25 \pm 0.37$ \\
\hline & Dicot & $7.90 \pm 0.77$ & $6.11 \pm 0.46$ & $6.56 \pm 0.71$ & $7.25 \pm 0.59$ \\
\hline \multirow[t]{3}{*}{ Cotyledon } & Monocot & $1.80 \pm 0.30^{\mathrm{a}}$ & $3.00 \pm 0.46^{\mathrm{b}}$ & $1.67 \pm 0.17^{\mathrm{a}}$ & $1.75 \pm 0.37^{\mathrm{a}}$ \\
\hline & Fern & $0.10 \pm 0.10$ & - & - & $0.13 \pm 0.13$ \\
\hline & Forb & $0.60 \pm 0.22$ & $1.00 \pm 0.17$ & $1.33 \pm 0.37$ & $0.50 \pm 0.19$ \\
\hline \multirow[t]{4}{*}{ Vegetation Type } & Graminoid & $1.70 \pm 0.26^{\mathrm{a}}$ & $3.00 \pm 0.24^{\mathrm{b}}$ & $1.67 \pm 0.17^{\mathrm{a}}$ & $1.75 \pm 0.37^{\mathrm{a}}$ \\
\hline & Herbaceous & $2.70 \pm 0.50$ & $2.22 \pm 0.15$ & $2.00 \pm 0.24$ & $1.63 \pm 0.50$ \\
\hline & Tree & $2.63 \pm 0.26^{\mathrm{a}, \mathrm{b}}$ & $1.80 \pm 0.33^{\mathrm{a}, \mathrm{b}}$ & $1.78 \pm 0.28^{\mathrm{a}}$ & $1.11 \pm 0.20^{\mathrm{b}}$ \\
\hline & Vine & $2.63 \pm 0.18^{\mathrm{a}}$ & $3.00 \pm 0.57^{\mathrm{b}}$ & $1.11 \pm 0.35^{\mathrm{a}, \mathrm{b}}$ & $2.11 \pm 0.35^{\mathrm{a}, \mathrm{b}}$ \\
\hline \multirow[t]{3}{*}{ Seed Size } & Small Seed & $1.40 \pm 0.34$ & $1.40 \pm 0.24$ & $1.22 \pm 0.67$ & $1.75 \pm 0.53$ \\
\hline & Medium Seed & $5.70 \pm 0.54$ & $6.20 \pm 0.43$ & $5.44 \pm 0.67$ & $5.00 \pm 0.50$ \\
\hline & Large Seed & $2.70 \pm 0.50$ & $1.44 \pm 0.41$ & $1.55 \pm 0.41$ & $2.38 \pm 0.18$ \\
\hline \multirow[t]{2}{*}{ Native Status } & Native & $7.80 \pm 0.68$ & $7.22 \pm 0.52$ & $7.20 \pm 0.56$ & $6.75 \pm 0.70$ \\
\hline & Invasive & $2.00 \pm 0.26$ & $1.89 \pm 0.35$ & $1.22 \pm 0.22$ & $2.38 \pm 0.18$ \\
\hline \multirow[t]{3}{*}{ Growth Habit } & Erect & $5.60 \pm 0.56$ & $6.44 \pm 0.60$ & $5.40 \pm 0.56$ & $5.75 \pm 0.75$ \\
\hline & Prostrate & $0.80 \pm 0.45$ & $0.89 \pm 0.20$ & $0.67 \pm 0.17$ & $0.50 \pm 0.27$ \\
\hline & Trailing & $3.40 \pm 0.40^{\mathrm{a}}$ & $1.78 \pm 0.47^{\mathrm{b}}$ & $2.11 \pm 0.39^{\mathrm{a}, \mathrm{b}}$ & $2.88 \pm 0.13^{\mathrm{a}, \mathrm{b}}$ \\
\hline \multirow[t]{2}{*}{ Root Structure } & Taproot & $6.60 \pm 0.72$ & $5.78 \pm 0.34$ & $5.89 \pm 0.56$ & $6.25 \pm 0.68$ \\
\hline & Fibrous & $3.20 \pm 0.36$ & $3.33 \pm 0.33$ & $2.33 \pm 0.29$ & $2.88 \pm 0.48$ \\
\hline
\end{tabular}

Letter codes designate statistical grouping. Rows lacking letter codes have no significant differences present. Bold text signifies a significant difference from reference values. 
Community weighted means (CWM) revealed significant differences across treatments for several functional traits. CWM for species native status exhibited significant reductions $(\mathrm{F}=3.59, \mathrm{p}=0.02)$ for TNT relative to RDX $(p=0.03)$ and reference $(p=0.04)$ plots. A similar trend was observed for life history $(F=3.78, p=0.02)$ as values for TNT plots were significantly lower than those of RDX $(p=0.04)$ and reference $(p=0.03)$ ones. TNT plots also exhibited significantly higher CWM values for photosynthetic mechanism $(\mathrm{F}=4.76, \mathrm{p}=0.01)$ compared to RDX $(p=0.01)$ and reference $(p=0.03)$. Despite these differences cluster analysis was unable to produce any distinctive pattern and the MRPP was unable to define the preexisting grouping scheme $(\mathrm{A}=$ $-0.004, \mathrm{p}=0.48)$.

\section{Discussion}

Due to the inherent risk of injury at many locations where unexploded ordnance (UXOs) are present, field monitoring of vegetative responses is rare; legacy community level information is even more so. As such, the objective of our study was to investigate and quantify long term impacts of explosives soil contamination on a vegetative community. Our initial hypotheses were that 1) community richness and diversity in contaminated areas would not exhibit change from reference plots as species would fill in vacant niches, 2) species composition would differ from reference plots as the presence of contaminants filtered out intolerant species, and 3) species functional traits would differ in contaminated plots relative to those of reference. Based on the results presented here all three hypotheses were supported.

Presence or absence of explosives compounds was unable to differentiate treatment groups from one another using standard species diversity metrics $\left(S, H^{\prime}, D_{1}\right)$. Woch et al. (2016) [7] found a similar response along a heavy metal gradient and suggested that similarity was due to less tolerant species being removed and more tolerant species coming in and establishing in the newly formed gaps and this trend had also been observed repeatedly in systems under natural disturbance regimes [57]-[61]. This idea is further supported by the significant increase in annual and monocot species presence in RDX plots as well as the increase in annuals CWM in TNT plots. Such shifts are common on disturbed sites and thought to have increased tolerance for contaminant presence [62]-[66]. There were shifts towards graminoid dominance in RDX plots. Graminoid species are highly resilient to RDX presence [67], however, graminoids are sensitive to TNT and other explosive mixtures [67] [68]. TNT plots showed a novel shift in functional dominance, via CWM values, with the significant increase in $\mathrm{C}_{4}$ plant presence. This dominance of $\mathrm{C}_{4}$ species in TNT plots is particularly interesting as TNT induces significant impacts to photosynthetic mechanisms yet $\mathrm{C}_{4}$ species appear to be more tolerant overall to presence of explosive compounds, and may have led to this shift [69].

Simpson's index of similarity showed that species composition was $\sim 60 \%$ or less similar for all treatment groups when all species were considered. Given the proximity of the plots $(5-50 \mathrm{~m})$ and the homogeneity of both soil and terrain the logical cause of this difference was the presence of contaminants. Observed similarities in community composition appeared to be largely driven by herbaceous species as there was little change in index values when woody species were removed from the analysis. In contrast woody species composition exhibited high variance in similarity across groups with values being as low as $14 \%$ and as high as $43 \%$. Reduced species similarity and alterations to dominant functional groups among plots in conjunction with a lack of change for species richness and diversity suggest that compositionally plots were also different across treatment groups. It appeared that the field plots exhibited an altered successional trajectory emphasizing the need to investigate broad scale effects of anthropogenic activities on natural systems.

Community composition produced the clearest differentiation of plots with three distinct groups 1) reference, 2) single contaminant, and 3) multiple contaminant plots. Functionally differences were observed for TNT and RDX in terms of representative species count (Figure 4) and CWM values, yet there were no significant impacts for Comp B plots. Similar response patterns have been observed at the individual scale for both morphological and physiological characteristics [70]. TNT appears to influence belowground structures and photosynthetic operation while RDX impacts aboveground structures as well as photosynthetic operation [70]-[72]. Unlike the two constituent compounds, Comp B tends to produce reduced impacts, requiring larger concentrations to induce the same level of impairment at the species level. Differences were present for CWM values denoting shifts in dominant traits between treatment groups [73] and potentially altering ecosystem processes [74] [75].

Small scale impacts of disturbance can have significant direct and indirect influences on larger scale processes [76]. At the individual level explosives have an array of morphological and physiological impacts on vegetation [3] which can influence success and fecundity of colonizing species [6]. By limiting intolerant species and pro- 


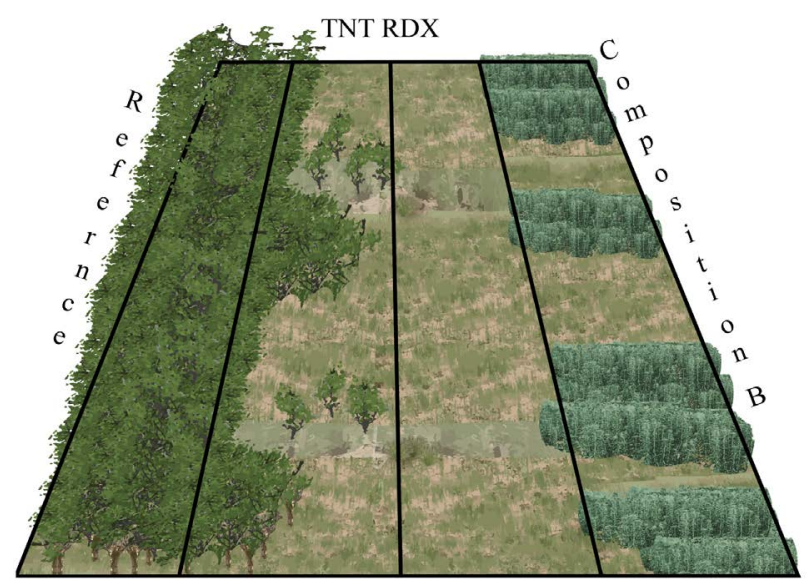

Figure 4. Graphical representation of community shifts across treatment area.

viding niches for tolerant ones contaminants act the same way that environmental filters do [1]. Considerable effort has been put into understanding short term impacts of anthropogenic contaminants on vegetative health, but more work is needed investigating long term impacts of exotoxins.

Species diversity and composition cannot fully explain ecosystem level impacts of a disturbance. By quantifying functional traits and composition of a community a much more complete understanding of disturbance effects and influences on recolonization trends can be gained [15] [77]-[81]. From a functional trait perspective there was less distinction among treatment groups, with most shifts occurring in RDX contaminated areas. RDX plots had far more annuals, monocots, graminoids and vines, as well as fewer animal dispersed species. Increases in annuals and graminoids have been observed in the presence of contaminants [62] [63] [66]. Compositional changes away from zoochorous species has been connected with harsh habitats; particularly young or disturbed ones [7] [82]. Functional richness and divergence have often been linked to community assembly processes [83]-[85] or ecosystem functioning [86]-[88].

Our results suggest that long-term impacts of explosives contamination affect community composition and functional traits from chronic leaching of point source toxic compounds over nearly two decades. The dummy mines were designed and placed in the field to closely mimic anti-personnel landmines allowing for direct comparisons to locations with UXO presence. Given the global distribution of UXOs and the continued use of landmines [3] understanding the ecological impacts of these devices is of great importance. Concentration of UXOs at the field site is relatively small suggesting that vegetative community condition on contaminated systems (military training grounds, past and current warzones, industrial landscapes, etc.) may exhibit more significant responses. While UXOs have devastating impacts to human life and health they also pose a serious ecological risk both from physical damage via explosive potential and from toxic compounds that may enter the soil.

Legacy community level impacts of explosive compounds are capable of being identified using various species and functional trait metrics. Presence of explosive compounds had impacts on community species and functional composition yet elicited no response in standard species diversity metrics. RDX and TNT contaminated plots had shifts in dominant functional traits, suggesting an influx of more tolerant species. RDX possessed the most unique combination of functional traits relative to reference and other treatment groups. Comp B had no significant impact on any metric which agreed with findings in recent literature. More long term broad scale investigation of contaminants and disturbance are needed to fully understand anthropogenic impacts on natural systems.

\section{Acknowledgements}

The authors would like to thank Paul Manley for assisting with data collection and species identification.

\section{References}

[1] Lambers, H., Chapin, F.S. and Pons, T.L. (2008) Plant Physiological Ecology. Springer New York, New York. http://dx.doi.org/10.1007/978-0-387-78341-3 
[2] Hansen, W.D., Romme, W.H., Ba, A. and Turner, M.G. (2016) Shifting Ecological Filters Mediate Postfire Expansion of Seedling Aspen (Populus tremuloides) in Yellowstone. Forest Ecology and Management, 362, 218-230. http://dx.doi.org/10.1016/j.foreco.2015.12.012

[3] Via, S.M. and Zinnert, J.C. (2016) Impacts of Explosive Compounds on Vegetation: A Need for Community Scale Investigations. Environmental Pollution, 208, 495-505. http://dx.doi.org/10.1016/j.envpol.2015.10.020

[4] Newman, M.C. and Clements, W. (2008) Biotic and Abiotic Factors That Regulate Communities. In: Newman, M.C. and Clements, W., Eds., Ecotoxicology. A Comprehensive Treatment, Taylor and Francis/CRC Press, Boca Raton, 379-407.

[5] Kim, T.N., Spiesman, B.J., Buchanan, A.L., Hakes, A.S., Halpern, S.L., Inouye, B.D. and Kilanowski, A.L. (2015) Selective Manipulation of a Non-Dominant Plant and Its Herbivores Affects an Old-Field Plant Community. Plant Ecology, 216, 1029-1045. http://dx.doi.org/10.1007/s11258-015-0487-3

[6] Prach, K., Rehounková, K., Lencová, K., Jirová, A., Konvalinková, P., Mudrák, O., Študent, V., Vaněček, Z., Tichý, L., Petř́ik, P. and Šmilauer, P. (2014) Vegetation Succession in Restoration of Disturbed Sites in Central Europe: The Direction of Succession and Species Richness across 19 Seres. Applied Vegetation Science, 17, 193-200. http://dx.doi.org/10.1111/avsc.12064

[7] Woch, M.W., Kapusta, P. and Stefanowicz, A.M. (2016) Variation in Dry Grassland Communities along a Heavy Metals Gradient. Ecotoxicology, 25, 80-90. http://dx.doi.org/10.1007/s10646-015-1569-7

[8] Brady, C.J. and Noske, R.A. (2010) Succession in Bird and Plant Communities over a 24-Year Chronosequence of Mine Rehabilitation in the Australian Monsoon Tropics. Restoration Ecology, 18, 855-864. http://dx.doi.org/10.1111/j.1526-100X.2008.00511.x

[9] Zhang, H. and Chu, L.M. (2011) Plant Community Structure, Soil Properties and Microbial Characteristics in Revegetated Quarries. Ecological Engineering, 37, 1104-1111. http://dx.doi.org/10.1016/j.ecoleng.2010.05.010

[10] Pandey, B., Agrawal, M. and Singh, S. (2014) Coal Mining Activities Change Plant Community Structure Due to Air Pollution and Soil Degradation. Ecotoxicology, 23, 1474-1483. http://dx.doi.org/10.1007/s10646-014-1289-4

[11] Woodwell, G.M. and Rebuck, A.L. (1967) Effects of Chronic Gamma Radiation on the Structure and Diversity of an Oak-Pine Forest. Ecological Monographs, 37, 53-69. http://dx.doi.org/10.2307/1948482

[12] Cardinale, B.J., Srivastava, D.S., Duffy, J.E., Wright, J.P., Downing, A.L., Sankaran, M. and Jouseau, C. (2006) Effects of Biodiversity on the Functioning of Trophic Groups and Ecosystems. Nature, 443, 989-992. http://dx.doi.org/10.1038/nature05202

[13] Cadotte, M.W., Cavender-Bares, J., Tilman, D. and Oakley, T.H. (2009) Using Phylogenetic, Functional and Trait Diversity to Understand Patterns of Plant Community Productivity. PLoS ONE, 4, e5695. http://dx.doi.org/10.1371/journal.pone.0005695

[14] Flynn, D.F.B., Mirotchnick, N., Jain, M., Palmer, M.I. and Naeem, S. (2011) Functional and Phylogenetic Diversity as Predictors of Biodiversity-Ecosystem Function Relationships. Ecology, 92, 1573-1581. http://dx.doi.org/10.1890/10-1245.1

[15] Feng, G., Svenning, J.C., Mi, X., Jia, Q., Rao, M., Ren, H., Bebber, D.P. and Ma, K. (2014) Anthropogenic Disturbance Shapes Phylogenetic and Functional Tree Community Structure in a Subtropical Forest. Forest Ecology and Management, 313, 188-198. http://dx.doi.org/10.1016/j.foreco.2013.10.047

[16] Klein, W. and Scheunert, I. (1982) Bound Pesticide Residues in Soil, Plants and Food with Particular Emphasis on the Application of Nuclear Techniques. International Symposium on Agrochemicals: Fate in Food and the Environment Using Isotope Techniques, Rome, 7-11 June 1982, 177-205. http://agris.fao.org/agris-search/search.do?recordID=XF19830921203

[17] Rylott, E.L. and Bruce, N.C. (2009) Plants Disarm Soil: Engineering Plants for the Phytoremediation of Explosives. Trends in Biotechnology, 27, 73-81. http://dx.doi.org/10.1016/j.tibtech.2008.11.001

[18] Russell, D.L. (2011) Costs of Remedial Activities. In: Russell, D.L., Ed., Remediation Manual for Contaminated Sites, CRC Press, Boca Raton, 145-158. http://dx.doi.org/10.1201/b11206-5

[19] Ansari, A.A., Gill, S.S., Gill, R., Lanza, G.R. and Newman, L. (Eds.) (2015) Phytoremediation: Management of Environmental Contaminants. Vol. 1, Springer International Publishing, Gewerbestrasse.

[20] Eschtruth, A.K. and Battles, J.J. (2014) Ephemeral Disturbances Have Long-Lasting Impacts on Forest Invasion Dynamics. Ecology, 95, 1770-1779. http://dx.doi.org/10.1890/13-1980.1

[21] Holl, K.D. (2002) Long-Term Vegetation Recovery on Reclaimed Coal Surface Mines in the Eastern USA. Journal of Applied Ecology, 39, 960-970. http://dx.doi.org/10.1046/j.1365-2664.2002.00767.x

[22] Travis, E.R., Bruce, N.C. and Rosser, S.J. (2008) Microbial and Plant Ecology of a Long-Term TNT-Contaminated Site. Environmental Pollution (Barking, Essex: 1987), 153, 119-126. http://dx.doi.org/10.1016/j.envpol.2007.07.015

[23] Huopalainen, M., Tuittila, E., Vanha-Majamaa, I., Nousiainen, J. and Vasander, H. (2000) The Potential of Soil Seed 
Banks for Revegetation of Bogs in SW Finland after Long-Term Aerial Pollution. Annales Botanici Fennici, 37, 1-9.

[24] Huopalainen, M., Tuittila, E.S., Vanha-Majamaa, I., Nousiainen, H., Laine, J. and Vasander, H. (2001) Effects of Long-Term Aerial Pollution on Soil Seed Banks in Drained Pine Mires in Southern Finland. Water, Air, and Soil Pollution, 125, 69-79. http://dx.doi.org/10.1023/A:1005276201740

[25] Walsh, M.R., Walsh, M.E., Ramsey, C.A., Thiboutot, S. and Ampleman, G. (2015) Energetics Residues Deposition from Training with Large Caliber Weapon Systems. European Conference of Defence and the Environment Conference Proceedings, 100-109.

[26] Cunningham, S.D., Berti, W.R. and Huang, J.W. (1995) Phytoremediation of Contaminated Soils. Trends in Biotechnology, 13, 393-397. http://dx.doi.org/10.1016/S0167-7799(00)88987-8

[27] Pilon-Smits, E. (2005) Phytoremediation. Annual Review of Plant Biology, 56, 15-39. http://dx.doi.org/10.1146/annurev.arplant.56.032604.144214

[28] Pilon-Smits, E.A. and Freeman, J.L. (2006) Environmental Cleanup Using Plants: Biotechnological Advances and Ecological Considerations. Frontiers in Ecology and the Environment, 4, 203-210. http://dx.doi.org/10.1890/1540-9295(2006)004[0203:ECUPBA]2.0.CO;2

[29] Wenzel, W.W. (2009) Rhizosphere Processes and Management in Plant-Assisted Bioremediation (Phytoremediation) of Soils. Plant and Soil, 321, 385-408. http://dx.doi.org/10.1007/s11104-008-9686-1

[30] Zhuang, J., Yu, H.Q., Henry, T.B. and Sayler, G.S. (2015) Fate and Toxic Effects of Environmental Stressors: Environmental Control. Ecotoxicology, 24, 2043-2048. http://dx.doi.org/10.1007/s10646-015-1567-9

[31] Flynn, D.F.B., Gogol-Prokurat, M., Nogeire, T., Molinari, N., Richers, B.T., Lin, B.B., Simpson, N., Mayfield, M.M. and DeClerck, F. (2009) Loss of Functional Diversity under Land Use Intensification across Multiple Taxa. Ecology Letters, 12, 22-33. http://dx.doi.org/10.1111/j.1461-0248.2008.01255.x

[32] Vandewalle, M., Purschke, O., de Bello, F., Reitalu, T., Prentice, H.C., Lavorel, S., Johansson, L.J. and Sykes, M.T. (2014) Functional Responses of Plant Communities to Management, Landscape and Historical Factors in Semi-Natural Grasslands. Journal of Vegetation Science, 25, 750-759. http://dx.doi.org/10.1111/jvs.12126

[33] Kusumoto, B., Shiono, T., Miyoshi, M., Maeshiro, R., Fujii, S.J., Kuuluvainen, T. and Kubota, Y. (2015) Functional Response of Plant Communities to Clearcutting: Management Impacts Differ between Forest Vegetation Zones. Journal of Applied Ecology, 52, 171-180. http://dx.doi.org/10.1111/1365-2664.12367

[34] Bond, B.J. (2000) Age-Related Changes in Photosynthesis of Woody Plants. Trends in Plant Science, 5, 349-353. http://dx.doi.org/10.1016/S1360-1385(00)01691-5

[35] Donaldson, J.R., Stevens, M.T., Barnhill, H.R. and Lindroth, R.L. (2006) Age-Related Shifts in Leaf Chemistry of Clonal Aspen (Populus tremuloides). Journal of Chemical Ecology, 32, 1415-1429. http://dx.doi.org/10.1007/s10886-006-9059-2

[36] Juvany, M., Müller, M. and Munné-Bosch, S. (2013) Plant Age-Related Changes in Cytokinins, Leaf Growth and Pigment Accumulation in Juvenile Mastic Trees. Environmental and Experimental Botany, 87, 10-18. http://dx.doi.org/10.1016/j.envexpbot.2012.09.007

[37] Collins, C., Fryer, M. and Grosso, A. (2006) Plant Uptake of Non-Ionic Organic Chemicals. Environmental Science and Technology, 40, 45-52. http://dx.doi.org/10.1021/es0508166

[38] Verkleij, J.A.C., Golan-Goldhirsh, A., Antosiewisz, D.M., Schwitzguébel, J.-P. and Schröder, P. (2009) Dualities in Plant Tolerance to Pollutants and Their Uptake and Translocation to the Upper Plant Parts. Environmental and Experimental Botany, 67, 10-22. http://dx.doi.org/10.1016/j.envexpbot.2009.05.009

[39] Hawari, J., Halasz, A., Sheremata, T., Beaudet, S., Groom, C., Paquet, L., Rhofir, C., Ampleman, G. and Thiboutot, S. (2000) Characterization of Metabolites during Biodegradation of Hexahydro-1,3,5-trinitro-1,3,5-triazine (RDX) with Municipal Anaerobic Sludge. Applied and Environmental Microbiology, 66, 2652-2657. http://dx.doi.org/10.1128/AEM.66.6.2652-2657.2000

[40] Khatisashvili, G., Gordeziani, M., Adamia, G., Kvesitadze, E., Sadunishvili, T. and Kvesitadze, G. (2009) Higher Plants Ability to Assimilate Explosives. World Academy of Science, Engineering and Technology, 33, 256-270.

[41] Pichtel, J. (2012) Distribution and Fate of Military Explosives and Propellants in Soil: A Review. Applied and Environmental Soil Science, 2012, Article ID: 617236. http://dx.doi.org/10.1155/2012/617236

[42] ORNL (Oak Ridge National Laboratory) (1999) Reducing the Threat of War and Terrorism. Oak Ridge National Laboratory Review, 32, 9-11. http://web.ornl.gov/info/ornlreview/meas_tech/threat.htm

[43] Fischer, R., Burlage, R., John, D. and Maston, M. (2000) Using Flourescence Imagery and Microbes for Ordnance and Mine Detection. Army AL\&T, 10-12.

[44] USGS (United States Geological Survey) (2016) Web Soil Survey (WSS). http://websoilsurvey.sc.egov.usda.gov/App/HomePage.htm 
[45] Oxley, J.C., Smith, J.L., Resende, E. and Pearce, E. (2003) Quantification and Aging of the Post-Blast Residue of TNT Landmines. Journal of Forensic Science, 48, 742-753. http://dx.doi.org/10.1520/JFS2002404

[46] Cardona, L., Jiménes, J. and Vanegas, N. (2014) Landmine Detection Techniques to Face the Demining Problem in Amtioquia. DYNA, 81, 115-125. http://dx.doi.org/10.15446/dyna.v81n183.37441

[47] McCune, B. and Grace, J.B. (2002) Analysis of Ecological Communities. MjM Software Design, Gleneden Beach.

[48] Morris, E.K., Caruso, T., Buscot, F., Fischer, M., Hancock, C., Maier, T.S., Meiners, T., Müller, C., Obermaier, E., Prati, D. and Socher, S.A. (2014) Choosing and Using Diversity Indices: Insights for Ecological Applications from the German Biodiversity Exploratories. Ecology and Evolution, 4, 3514-3524. http://dx.doi.org/10.1002/ece3.1155

[49] Radford, A.E., Ahles, H.E. and Bell, C.R. (2010) Manual of the Vascular Flora of the Carolinas. University of North Carolina Press, Ithaca.

[50] Uva, R., Neal, J. and DiTomaso, J. (1997) Weeds of the Northeast. Cornell University Press, Ithaca.

[51] Bryson, C. and DeFelice, M. (Eds.) (2009) Weeds of the South. The University of Georgia Press, Athens.

[52] Porcher, R. and Rayner, D. (2001) A Guide to the Wildflowers of South Carolina. University of South Carolina, Colombia.

[53] Del Tredici, P. (2010) Wild Urban Plants of the Northeast: A Field Guide. A Comstock Book of Cornell University Press, Ithaca.

[54] Garnier, E., Cortez, J., Billes, G., Navas, M.L., Roumet, C., Debussche, M., Laurent, G., Blanchard, A., Aubry, D., Bellmann, A., Neill, C. and Toussaint, J.P. (2004) Plant Functional Markers Capture Ecosystem Properties during Secondary Succession. Ecology, 85, 2630-2637. http://dx.doi.org/10.1890/03-0799

[55] Laliberté, E., Legendre, P. and Shipley, B. (2014) FD: Measuring Functional Diversity from Multiple Traits, and Other Tools for Functional Ecology. R Package Version 1.0-12.

[56] Ricotta, C. and Moretti, M. (2011) CWM and Rao’s Quadratic Diversity: A Unified Framework for Functional Ecology. Oecologia, 167, 181-188. http://dx.doi.org/10.1007/s00442-011-1965-5

[57] Bobbink, R. (1991) Effects of Nutrient Enrichment in Dutch Chalk Grassland. Journal of Applied Ecology, 28, 28-41. http://dx.doi.org/10.2307/2404111

[58] Barbaro, L., Dutoit, T., Anthelmea, F. and Corcket, E. (2004) Respective Influence of Habitat Conditions and Management Regimes on Pre-Alpine Calcareous Grasslands. Journal of Environmental Management, 72, 261-275. http://dx.doi.org/10.1016/j.jenvman.2004.05.006

[59] Questad, E.J. and Foster, B.L. (2007) Vole Disturbances and Plant Diversity in a Grassland Metacommunity. Oecologia, 153, 341-351. http://dx.doi.org/10.1007/s00442-007-0734-y

[60] Stevens, C.J., Thompson, K., Grime, J.P., Long, C.J. and Gowing, D.J.G. (2010) Contribution of Acidification and Eutrophication to Declines in Species Richness of Calcifuge Grasslands along a Gradient of Atmospheric Nitrogen Deposition. Functional Ecology, 24, 478-484. http://dx.doi.org/10.1111/j.1365-2435.2009.01663.x

[61] Kurek, P., Kapusta, P. and Holeksa, J. (2014) Burrowing by Badgers (Meles meles) and Foxes (Vulpes vulpes) Changes Soil Conditions and Vegetation in a European Temperate Forest. Ecological Research, 29, 1-11. http://dx.doi.org/10.1007/s11284-013-1094-1

[62] Schnoor, J.L., Light, L.A., McCutcheon, S.C., Wolfe, N.L. and Carreia, L.H. (1995) Phytoremediation of Organic and Nutrient Contaminants. Environmental Science \& Technology, 29, 318A-323A. http://dx.doi.org/10.1021/es00007a747

[63] Quist, M.C., Fay, P.A., Guy, C.S., Knapp, A.K. and Rubenstein, B.N. (2003) Military Training Effects on Terrestrial and Aquatic Communities on a Grassland Military Installation. Ecological Applications, 13, 432-442. http://dx.doi.org/10.1890/1051-0761(2003)013[0432:MTEOTA]2.0.CO;2

[64] Winfield, L.E., Rodger, J.H. and D’surney, S.J. (2004) The Responses of Selected Terrestrial Plants to Short $(<12$ Days) and Long Term (2, 4 and 6 Weeks) Hexahydro-1,3,5-trinitro-1,3,5-triazine (RDX) Exposure. Part I: Growth and Developmental Effects. Ecotoxicology, 13, 335-347. http://dx.doi.org/10.1023/B:ECTX.0000033091.78180.3d

[65] Panz, K., Miksch, K. and Sójka, T. (2013) Synergetic Toxic Effect of an Explosive Material Mixture in Soil. Bulletin of Environmental Contamination and Toxicology, 91, 555-559. http://dx.doi.org/10.1007/s00128-013-1090-8

[66] Zhang, H. and Chu, L.M. (2013) Changes in Soil Seed Bank Composition during Early Succession of Rehabilitated Quarries. Ecological Engineering, 55, 43-50. http://dx.doi.org/10.1016/j.ecoleng.2013.02.002

[67] Best, E.P., Smith, T., Hagen, F.L., Dawson, J. and Torrey, A.J. (2007) Candidate Herbaceous Plants for Phytoremediation of Energetics on Ranges. http://oai.dtic.mil/oai/oai?verb=getRecord\&metadataPrefix=html\&identifier=ADA472128

[68] Peterson, M.M., Horst, G.L., Shea, P.J. and Comfort, S.D. (1998) Germination and Seedling Development of Switchgrass and Smooth Bromegrass Exposed to 2,4,6-Trinitrotoluene. Environmental Pollution, 99, 53-59. http://dx.doi.org/10.1016/S0269-7491(97)00175-9 
[69] Via, S.M. and Zinnert, J.C. (2016) Multiple Metrics Quantify and Differentiate Responses of Vegetation to Composition B. International Journal of Phytoremediation. (In Press)

[70] Via, S.M., Zinnert, J.C., Butler, A.D. and Young, D.R. (2014) Comparative Physiological Responses of Morella cerifera to RDX, TNT, and Composition B Contaminated Soils. Environmental and Experimental Botany, 99, 67-74. http://dx.doi.org/10.1016/j.envexpbot.2013.11.002

[71] Via, S.M., Zinnert, J.C. and Young, D.R. (2015) Differential Effects of Two Explosive Compounds on Seed Germination and Seedling Morphology of a Woody Shrub, Morella cerifera. Ecotoxicology (London, England), 24, 194-201. http://dx.doi.org/10.1007/s10646-014-1372-X

[72] Zinnert, J.C., Via, S.M. and Young, D.R. (2013) Distinguishing Natural from Anthropogenic Stress in Plants: Physiology, Fluorescence and Hyperspectral Reflectance. Plant and Soil, 366, 133-141. http://dx.doi.org/10.1007/s11104-012-1414-1

[73] Villéger, S., Mason, N.W.H. and Mouillot, D. (2008) New Multidimensional Functional Diversity Indices for a Multifaceted Framework in Functional Ecology. Ecology, 89, 2290-2301. http://dx.doi.org/10.1890/07-1206.1

[74] Vile, D., Shipley, B. and Garnier, E. (2006) Ecosystem Productivity Can Be Predicted from Potential Relative Growth Rate and Species Abundance. Ecology Letters, 9, 1061-1067. http://dx.doi.org/10.1111/j.1461-0248.2006.00958.x

[75] Mokany, K., Ash, J. and Roxburgh, S. (2008) Functional Identity Is More Important than Diversity in Influencing Ecosystem Processes in a Temperate Native Grassland. Journal of Ecology, 96, 884-893. http://dx.doi.org/10.1111/j.1365-2745.2008.01395.x

[76] Heffernan, J.B., Soranno, P.A., Angilletta, M.J., Buckley, L.B., Gruner, D.S., Keitt, T.H., Kellner, J.R., Kominoski, J.S., Rocha, A.V., Xiao, J. and Harms, T.K. (2014) Macrosystems Ecology: Understanding Ecological Patterns and Processes at Continental Scales. Frontiers in Ecology and the Environment, 12, 5-14. http://dx.doi.org/10.1890/130017

[77] Ding, Y., Zang, R.G., Letcher, S.G., Liu, S.R. and He, F.L. (2012) Disturbance Regime Changes the Trait Distribution, Phylogenetic Structure and Community Assembly of Tropical Rain Forests. Oikos, 121, 1263-1270. http://dx.doi.org/10.1111/j.1600-0706.2011.19992.x

[78] Letcher, S.G. (2010) Phylogenetic Structure of Angiosperm Communities during Tropical Forest Succession. Proceedings of the Royal Society of London: Biological Sciences, 277, 97-104. http://dx.doi.org/10.1098/rspb.2009.0865

[79] Letcher, S.G., Chazdon, R.L., Andrade, A.C.S., Bongers, F., Breugel, M., Finegan, B., Laurance, S.G., Mesquita, R.C.G., Martínez-Ramos, M. and Williamson, G.B. (2012) Phylogenetic Community Structure during Succession: Evidence from Three Neotropical Forest Sites. Perspectives in Plant Ecology, Evolution and Systematics, 14, 79-87. http://dx.doi.org/10.1016/j.ppees.2011.09.005

[80] Norden, N., Letcher, S.G., Boukili, V., Swenson, N.G. and Chazdon, R. (2012) Demographic Drivers of Successional Changes in Phylogenetic Structure across Life-History Stages in Plant Communities. Ecology, 93, S70-S82. http://dx.doi.org/10.1890/10-2179.1

[81] Whitfield, J. (2002) Ecology: Neutrality versus the Niche. Nature, 417, 480-481. http://dx.doi.org/10.1038/417480a

[82] Řehounková, K. and Prach, K. (2010) Life-History Traits and Habitat Preferences of Colonizing Plant Species in Long-Term Spontaneous Succession in Abandoned Gravel-Sand Pits. Basic and Applied Ecology, 11, 45-53. http://dx.doi.org/10.1016/j.baae.2009.06.007

[83] Mouchet, M.A., Villéger, S., Mason, N.W.H. and Mouillot, D. (2010) Functional Diversity Measures: An Overview of Their Redundancy and Their Ability to Discriminate Community Assembly Rules. Functional Ecology, 24, 867-876. http://dx.doi.org/10.1111/j.1365-2435.2010.01695.x

[84] Mason, N.W.H., Richardson, S.J., Peltzer, D.A., de Bello, F., Wardle, D.A. and Allen, R.B. (2012) Changes in Coexistence Mechanisms along a Long-Term Soil Chronosequence Revealed by Functional Trait Diversity. Journal of Ecology, 100, 678-689. http://dx.doi.org/10.1111/j.1365-2745.2012.01965.x

[85] Spasojevic, M.J. and Suding, K.N. (2012) Inferring Community Assembly Mechanisms from Functional Diversity Patterns: The Importance of Multiple Assembly Processes. Journal of Ecology, 100, 652-661. http://dx.doi.org/10.1111/j.1365-2745.2011.01945.x

[86] Petchey, O.L., Hector, A. and Gaston, K.J. (2004) How Do Different Measures of Functional Diversity Perform? Ecology, 85, 847-857. http://dx.doi.org/10.1890/03-0226

[87] Mason, N.W.H., De Bello, F., Mouillot, D., Pavoine, S. and Dray, S. (2013) A Guide for Using Functional Diversity Indices to Reveal Changes in Assembly Processes along Ecological Gradients. Journal of Vegetation Science, 24, 794806. http://dx.doi.org/10.1111/jvs.12013

[88] Mouillot, D., Graham, N.A.J., Villéger, S., Mason, N.W.H. and Bellwood, D.R. (2013) A Functional Approach Reveals Community Responses to Disturbances. Trends in Ecology and Evolution, 28, 167-177. http://dx.doi.org/10.1016/j.tree.2012.10.004 


\section{Submit or recommend next manuscript to SCIRP and we will provide best service for you:}

Accepting pre-submission inquiries through Email, Facebook, LinkedIn, Twitter, etc.

A wide selection of journals (inclusive of 9 subjects, more than 200 journals)

Providing 24-hour high-quality service

User-friendly online submission system

Fair and swift peer-review system

Efficient typesetting and proofreading procedure

Display of the result of downloads and visits, as well as the number of cited articles

Maximum dissemination of your research work

Submit your manuscript at: http://papersubmission.scirp.org/ 